\title{
Pengaruh Ketebalan Plastik Polietilen Densitas Rendah sebagai Bahan Kemasan terhadap Mutu Daun Seledri (Apium Gravelens L.) Selama Penyimpanan Dingin
}

\section{The Effect of Low-Density Polyethylene Plastics's Thickness as a Packaging Materials on the Quality of Celery (Apium gravelens L.) during Cold Storage}

\author{
I Kadek Puja Harta Hadi, Ida Ayu Rina Pratiwi Pudja*, Gede Arda \\ Program Studi Teknik Pertanian, Fakultas Teknologi Pertanian Universitas Udayana \\ *E-mail: rinapratiwi@unud.ac.id
}

\begin{abstract}
Salah satu cara yang dilakukan untuk mempertahankan kualitas daun seledri dan memperpanjang umur simpan adalah menggunakan pengemasan dengan ukuran ketebalan plastik polietilen densitas rendah (LDPE) yang tepat dan penyimpanan pada suhu rendah. Tujuan penelitian ini adalah untuk mengetahui pengaruh ketebalan plastik polietilen densitas rendah sebagai bahan kemasan terhadap mutu daun seledri selama penyimpanan dingin dan untuk mengetahui tingkat ketebalan plastik polietilen densitas rendah berapakah yang dapat mempertahankan mutu daun seledri yang terbaik. Metode penelitian ini menggunakan penelitian eksperimental. Rancangan percobaan yang digunakan adalah Rancangan Acak Lengkap (RAL) dengan perlakuan ketebalan plastik polietilen densitas rendah dengan ukuran ketebalan $0,02 \mathrm{~mm} ; 0,03 \mathrm{~mm} ; 0,04 \mathrm{~mm} ; 0,05 \mathrm{~mm}, 0,06 \mathrm{~mm}$. Pengamatan dilakukan setiap 3 hari sekali dan setiap perlakuan diulang sebanyak 3 kali pada suhu penyimpanan $10 \pm 2^{\circ} \mathrm{C}$ selama 18 hari penelitian. Parameter dalam penelitian ini adalah susut bobot, kadar air, warna, tekstur, tingkat kesegaran, dan aroma. Hasil analisis ragam menunjukkan bahwa perlakuan ketebalan plastik LDPE sebagai bahan kemasan daun seledri berpengaruh sangat nyata $(\mathrm{P}<0,01)$ terhadap parameter penelitian. Perlakuan terbaik diperoleh dari ketebalan plastik polietilen densitas rendah ukuran 0,04 mm dengan susut bobot 4,64 \%, warna 18,97, tekstur 0,0455 N, kadar air 90,22\%, tingkat kesegaran 4,87 dan aroma 5,00. Kesimpulan bahwa tingkat ketebalan plastik LDPE 0,04 dapat mempertahankan mutu daun seledri paling lama diantara ukuran ketebalan yang lainnya yaitu dengan umur simpan selama 18 hari.
\end{abstract}

Kata kunci: : Daun seledri, ketebalan plastik LDPE, penyimpanan dingin.

Using the right thickness of low-density polyethylene (LDPE) packaging can maintain the quality of celery and also can extend their storage time. The purpose of this study was to determine the effect of LDPE plastic thickness as a packaging material on the quality of celery during storage at low temperature and to determine which thickness level of LDPE plastic can maintain the best quality celery. Experimental research was used in this study. In this study, Completely Randomized Design (RAL) was used as experimental design. The thickness level that used for this study were $0.02 \mathrm{~mm} ; 0.03 \mathrm{~mm} ; 0.04 \mathrm{~mm} ; 0.05$ $\mathrm{mm}, 0.06 \mathrm{~mm}$. Observations were made once every 3 days and each treatment was repeated 3 times at a storage temperature of $10 \pm 2^{\circ} \mathrm{C}$ for 18 days. The parameters in this study were weight loss, water content, color, texture, freshness, and the scent. The results of the analysis of variance showed that the thickness level of LDPE plastic as packaging material for celery had a very significant effect $(\mathrm{P}<0.01)$ towards the research parameters. The best treatment was obtained from $0.04 \mathrm{~mm}$ size with a weight loss of $4.64 \%, 18.97$ on color, a texture of $0.0455 \mathrm{~N}$, a water content of $90.22 \%$, a freshness level of 4.87 and the scent of 5.00 . The conclusion that the thickness level at $0.04 \mathrm{~mm}$ of LDPE plastic is the best solution to maintain quality of celery and reached 18 days of storage time.

Keyword: celery, LDPE plastic's thickness, cold storage

\section{PENDAHULUAN}

Seledri merupakan salah satu komoditas hortikultura yang diperlukan oleh masyarakat karena bermanfaat untuk kesehatan (Arisandi dan Sukohar, 2016). Selain itu, daun seledri juga dimanfaatkan sebagai pelengkap bumbu sayuran (Elidar, 2018). Daun seledri mengandung vitamin A, B1, B2, B6, C, E, K, $\mathrm{P}$ dan mineral lain seperti $\mathrm{Fe}, \mathrm{Ca}, \mathrm{P}, \mathrm{Mg}$ dan $\mathrm{Zn}$. Vitamin $\mathrm{C}$ dalam seledri berfungsi untuk menguatkan sistem imun manusia. Kandungan $\mathrm{Ca}, \mathrm{P}$, dan $\mathrm{Mg}$ yang dapat memperkuat tubuh (Syahidah dan Sulistiyaningsih, 2018).

Setelah panen, daun seledri cenderung mengalami kemunduran mutu dikarenakan masih terjadi proses transpirasi yang dialami daun seledri. Umur simpan daun seledri relatif singkat yaitu berkisar 2 sampai 3 hari pada penyimpanan suhu ruang (Indrasari, 2009). Oleh karena umur simpan daun seledri yang relatif singkat maka diperlukan suatu cara penanganan dan 
perlakuan yang dapat menurunkan transpirasi untuk memperlambat kemunduran pasca panen daun seledri sampai batas minimal produk tersebut masih mampu melangsungkan aktivitas hidupnya.

Salah satu cara yang dapat menghambat kemunduran mutu suatu produk hortikultura yaitu pengemasan dengan plastik polietilen densitas rendah. Plastik polietilen densitas rendah (LDPE) merupakan plastik yang transparan, agak buram, kedap air, tidak mudah sobek serta baik digunakan untuk mengemas buahbuahan dan sayuran segar, roti, dan produk pangan beku (Budiyanto, 2012). Hal tersebut berkaitan dengan penelitian Saragih (2016) yang menyatakan bahwa ketebalan plastik LDPE terbukti dapat memperpanjang umur simpan sayuran.

Cara yang dilakukan untuk mempertahankan kualitas daun seledri dan memperpanjang umur simpan dapat dilakukan dengan penyimpanan pada suhu rendah. Selain itu, penggunaan plastik LDPE tertutup pada penyimpanan suhu dingin sangat efektif dalam memperpanjang umur simpan buah dan sayuran. Menurut Indrasari (2009), penyimpanan seledri pada suhu $10-15^{\circ} \mathrm{C}$ lebih awet daripada penyimpanan pada suhu ruang.

Berdasarkan kondisi tersebut, diperlukan penelitian lebih lanjut mengenai pengaruh ketebalan plastik polietilen densitas rendah sebagai bahan kemasan terhadap mutu daun seledri. Penelitian ini bertujuan untuk mengetahui pengaruh ketebalan plastik polietilen densitas rendah sebagai bahan kemasan terhadap mutu daun seledri selama penyimpanan dingin dan untuk mengetahui tingkat ketebalan plastik polietilen densitas rendah berapakah yang dapat mempertahankan mutu daun seledri yang terbaik. Pada penelitian ini membutuhkan ketelitian dalam melakukan pengukuran pada daun seledri, karena jika pengukuran tidak tepat maka tidak mendapatkan hasil yang maksimal.

\section{METODE PENELITIAN}

\section{Parameter yang Diamati}

Parameter yang diamati secara objektif yaitu susut bobot menggunakan timbangan digital, warna menggunakan colorimeter, tekstur menggunakan texture analyzer, dan kadar air menggunakan oven. Penilaian subjektif diamati pada parameter warna, tingkat kesegaran, tekstur dan aroma yang diamati pada hari ke-18 dengan menggunakan uji organoleptik.

\section{Susut Bobot}

Pengukuran nilai susut bobot dilakukan dengan menggunakan alat Timbangan Analitik AND GF300. Perubahan susut bobot daun seledri diukur dengan menimbang bobot daun seledri. Bobot awal sampel ditimbang sebelum daun seledri disimpan. Pengamatan selanjutnya adalah dengan menimbang sampel sebelum penyimpanan dan setelah penyimpanan. Susut bobot dapat dihitung berdasarkan rumus sebagai berikut:

$$
\Delta m(b b)=\frac{\text { berat }_{\text {awal }}-\text { berat }_{\text {akhir }}}{\text { berat }_{\text {awal }}} \times 100 \%
$$

Dimana $\Delta m(b b)$ adalah susut bobot basis basah.

\section{Color Difference}

Pengukuran nilai warna dilakukan dengan menggunakan alat Colorimeter PCE. Urutan kerja analisa warna dimulai dari menempelkan alat Colorimeter PCE pada sampel daun seledri yang diuji seberat 20 sampai 20,2 g yang kemudian menekan tombol yang ada dibelakang alat Colorimeter PCE. Proses selanjutnya mencatat hasil pengujian nilai L, a, dan b. Nilai L, a, dan b dianalisis dalam Ms. Exel untuk mendapatkan nilai rata-rata menggunakan rumus Color Difference. Nilai rata-rata yang didapatkan kemudian dianalisis dalam aplikasi SPSS 23. Perbedaan warna daun seledri dapat ditentukan dengan rumus Color Difference $(\Delta \mathrm{E})$ :

\section{Tekstur}

$$
\Delta E=\sqrt{\Delta L^{* 2}+\Delta a^{* 2}+\Delta b^{* 2}}
$$

Pengukuran nilai tekstur dilakukan dengan menggunakan alat Texture Analyzer (TA) XT Plus. Urutan kerja analisa tekstur dimulai dari mengatur kedalaman penusukan sampel pada TA setting. Selanjutnya dilakukan update project dengan klik new project dan memilih Graph. Proses selanjutnya menyiapkan daun seledri yang diuji seberat 20 sampai 20,2 gram kemudian klik TA pada menu bar dan klik quick run set. Catat nilai yang muncul pada kiri atas dengan satuan N. Prosedur ini dilakukan untuk menentukan tingkat kekerasan pada daun seledri.

\section{Kadar Air}

Penentuan kadar air didasarkan pada perbedaan berat sampel sebelum dan sesudah pemanasan. Prosedur analisa kadar air adalah sebagai berikut:

1. Cawan kosong yang digunakan dikeringkan dalam oven selama 1 jam, kemudian didinginkan selama 15 menit dalam desikator. Setelah dingin, berat cawan kosong kemudian ditimbang.

2. Sampel ditimbang seberat 3 gram kemudian dimasukkan dalam cawan kemudian dikeringkan dalam oven selama 4 jam pada suhu $105^{\circ} \mathrm{C}$.

3. Kemudian cawan didinginkan dalam desikator selama 30 menit dan setelah dingin ditimbang kembali.

4. Setelah ditimbang, cawan tersebut dikeringkan dalam oven selama 2 jam sehingga didapat berat konstan. 
Persentase kadar air dapat dihitung dengan rumus sebagai berikut:

Kadar air $(\%)=\underline{\text { berat basah }- \text { berat kering }} \times 100 \%$ berat basah

Evaluasi Sensori (Berdasarkan Uji Organoleptik)

Evaluasi sensori dilakukan dengan menggunakan uji organoleptik. Panelis dalam uji organoleptik penelitian ini adalah mahasiswa Universitas Udayana sebanyak 15 orang panelis. Uji organoleptik yang dilakukan dalam penelitian ini adalah uji skoring. Penilaian subjektif dengan menggunakan uji organoleptik menggunakan skor penilaian 1 sampai 5 pada parameter warna, tingkat kesegaran, tekstur dan aroma yang diamati pada hari ke-18.

\section{Tempat dan Waktu Penelitian}

Penelitian ini dilaksanakan di Laboratorium Teknik Pascapanen, Program Studi Teknik Pertanian Fakultas Teknologi Pertanian Universitas Udayana. Pelaksanaan penelitian ini dilakukan pada bulan Juni 2019 sampai Juli 2019.

\section{Alat dan Bahan Penelitian}

Alat yang digunakan dalam penelitian ini adalah timbangan digital (merk Adventurer TM pro Av 8101 ohaus, New York, USA), refrigerated show case (merk polytron), sealer, gunting, pisau, termometer air raksa, talenan plastik, timba, Colorimeter (Model No: PCE-CSM 1), texture analyzer (merk TA XT PLUS), oven listrik (Model No: DO 225-OECA3E5), cawan alumunium, desikator, mortar dan alu kuningan, dan pinset.

Bahan utama yang digunakan dalam penelitian ini adalah daun seledri segar dengan kriteria tidak mengalami kerusakan pada daun dan batang seledri dengan panjang antara $12-16 \mathrm{~cm}$ yang didapatkan dari petani di Desa Candikuning, Kecamatan Baturiti, Kabupaten Tabanan, Provinsi Bali. Bahan lain yang digunakan adalah plastik polietilen densitas rendah berukuran $20 \times 30 \mathrm{~cm}$ dengan ketebalan $0,02 \mathrm{~mm}$, $0,03 \mathrm{~mm}, 0,04 \mathrm{~mm}, 0,05 \mathrm{~mm}$, dan 0,06 $\mathrm{mm}$.

\section{Rancangan Penelitian}

Penelitian ini menggunakan Rancangan Acak Lengkap (RAL) dengan 1 faktor perlakuan yaitu ketebalan plastik polietilen densitas rendah. Perlakuan pada penelitian ini disimpan pada suhu penyimpanan $10 \pm 2^{\circ} \mathrm{C}$. Pengambilan data diambil setiap 3 hari sekali dimulai dari hari ke-0. Masingmasing dari perlakuan dilakukan pengulangan sebanyak 3 kali sehingga diperoleh 18 unit percobaan setiap satu kali pengujian. Pencatatan dilakukan secara langsung setiap pengamatan 3 hari sekali selama 18 hari penyimpanan. Data hasil pengamatan yang diperoleh, dianalisis dengan uji ragam dan apabila terdapat pengaruh perlakuan yang signifikan, dilanjutkan dengan uji Duncan terhadap rata-rata perlakuan. Ketebalan plastik LDPE yang digunakan adalah:

$\mathrm{P} 0=$ tanpa dikemas plastik LDPE

$\mathrm{P} 1=$ dikemas dalam plastik LDPE dengan ketebalan $0,02 \mathrm{~mm}$

$\mathrm{P} 2$ = dikemas dalam plastik LDPE dengan ketebalan $0,03 \mathrm{~mm}$

P3 = dikemas dalam plastik LDPE dengan ketebalan $0,04 \mathrm{~mm}$

P4 = dikemas dalam plastik LDPE dengan ketebalan $0,05 \mathrm{~mm}$

P5 = dikemas dalam plastik LDPE dengan ketebalan $0,06 \mathrm{~mm}$

\section{Pelaksanaan Penelitian \\ Penerimaan Bahan}

Daun seledri didapatkan dari petani di Desa Candikuning, Kecamatan Baturiti, Kabupaten Tabanan, Provinsi Bali. Panen daun seledri dilakukan pada pagi hari dengan jumlah seledri yang didapatkan sebanyak 2,5 kilogram. Daun seledri yang telah selesai dipanen dilanjutkan dengan proses pengepakan yang dimasukkan ke dalam styrofoam berisi es. Es dalam styrofoam tidak bersentuhan langsung dengan daun seledri melainkan dibatasi dengan menggunakan daun pisang sebagai pembatas, dan dibawa ke Laboratorium Teknik Pascapanen, Program Studi Teknik Pertanian, Fakultas Teknologi Pertanian, Universitas Udayana untuk penelitian selanjutnya. Kriteria daun seledri yang dipilih dalam penelitian ini adalah memiliki warna hijau segar, tekstur tegar, dan kenampakan segar.

\section{Sortasi}

Sortasi dilakukan untuk memilih daun seledri yang memenuhi kriteria penelitian yang dibutuhkan. Kriteria daun seledri yang dibutuhkan yaitu tidak rusak, tidak cacat, tidak luka secara mekanis, tidak busuk dan tidak terinfeksi oleh penyakit.

\section{Pencucian}

Pencucian dilakukan dengan cara mencelupkan daun seledri ke dalam wadah yang berisi air PDAM yang sudah didinginkan pada suhu $10^{\circ} \mathrm{C}$ yang didapatkan dengan cara mendinginkan air di show case selama 3 hari sebelum penelitian dilakukan. Jumlah air yang digunakan sebanyak 5 botol aqua $1500 \mathrm{ml}$. Proses pencucian bertujuan mempertahankan kesegaran daun seledri. Pencelupan produk dilakukan selama 20 detik. Pencucian dilakukan dengan tujuan untuk menghilangkan kotoran pada daun seledri. Setelah proses pencucian, kemudian daun seledri ditiriskan untuk beberapa saat sehingga air yang ada pada daun seledri berkurang. 


\section{Penimbangan}

Daun seledri yang telah dicuci bersih kemudian ditimbang beratnya masing-masing sebesar 20 gram sampai 20,2 gram. Penimbangan daun seledri menggunakan alat penimbangan digital.

\section{Pengemasan}

Pengemasan menggunakan plastik polietilen densitas rendah dengan ukuran $20 \times 30 \mathrm{~cm}$ dilakukan setelah proses penimbangan daun seledri. Proses pengemasan dimulai dengan daun seledri dimasukkan ke dalam plastik polietilen densitas rendah dan ujung plastik ditutup dengan menggunakan sealer, bagian yang disealer adalah ujung plastik dengan ukuran $1,5 \mathrm{~cm}$. Proses sealer bertujuan untuk menghambat oksigen $\left(\mathrm{O}_{2}\right)$ masuk ke dalam plastik.

\section{Penyimpanan}

Penyimpanan daun seledri yang sudah dikemas menggunakan plastik polietilen densitas rendah disimpan dalam lemari pendingin refrigerated show case dengan suhu $10 \pm 2^{\circ} \mathrm{C}$ selama 18 hari.

\section{HASIL DAN PEMBAHASAN}

\section{Susut Bobot}

Berdasarkan hasil analisis ragam menunjukkan bahwa pengemasan dengan perlakuan tingkat ketebalan plastik polietilen densitas rendah pada daun seledri berpengaruh sangat nyata $(\mathrm{P}<0,01)$ terhadap susut bobot seledri selama penyimpanan pada hari ke$3,6,9,12,15$, dan hari ke-18. Sedangkan pada hari ke-0 semua perlakuan tidak berpengaruh nyata $(\mathrm{P}>0,05)$. Adapun hasil uji ragam dari nilai rata-rata susut bobot pada daun seledri selama penyimpanan disajikan pada Tabel 1.

Tabel 1. Nilai Rata-rata Susut Bobot (\%) Daun Seledri.

\begin{tabular}{cccccccc}
\hline Perlakuan & Hari 0 & Hari 3 & Hari 6 & Hari 9 & Hari 12 & Hari 15 & Hari 18 \\
P0 & $20.0 \mathrm{a}$ & $6.66 \mathrm{a}$ & $13.33 \mathrm{a}$ & $31.83 \mathrm{a}$ & $33.66 \mathrm{a}$ & $36.33 \mathrm{a}$ & $37.83 \mathrm{a}$ \\
P1 & $23.9 \mathrm{a}$ & $1.95 \mathrm{c}$ & $5.57 \mathrm{~b}$ & $10.04 \mathrm{~b}$ & $11.58 \mathrm{~b}$ & $15.06 \mathrm{~b}$ & $15.76 \mathrm{~b}$ \\
P2 & $24.2 \mathrm{a}$ & $2.89 \mathrm{~b}$ & $3.72 \mathrm{c}$ & $3.85 \mathrm{~d}$ & $4.41 \mathrm{e}$ & $5.51 \mathrm{e}$ & $6.33 \mathrm{e}$ \\
P3 & $24.4 \mathrm{a}$ & $0.54 \mathrm{~d}$ & $1.36 \mathrm{~d}$ & $2.32 \mathrm{e}$ & $3.00 \mathrm{f}$ & $3.82 \mathrm{f}$ & $4.64 \mathrm{f}$ \\
P4 & $24.9 \mathrm{a}$ & $1.33 \mathrm{c}$ & $2.94 \mathrm{c}$ & $4.15 \mathrm{~d}$ & $6.96 \mathrm{~d}$ & $8.16 \mathrm{~d}$ & $9.64 \mathrm{~d}$ \\
P5 & $25.8 \mathrm{a}$ & $1.29 \mathrm{c}$ & $3.62 \mathrm{c}$ & $6.07 \mathrm{e}$ & $9.04 \mathrm{c}$ & $10.34 \mathrm{c}$ & $11.63 \mathrm{c}$ \\
\hline
\end{tabular}

Keterangan: Huruf yang sama dibelakang nilai rata-rata pada kolom yang sama menunjukkan nilai yang tidak berbeda nyata $(\mathrm{P}>0,05)$.

Nilai rata-rata susut bobot terendah adalah $4,64 \%$ terdapat pada perlakuan P3 karena kenaikan susut bobot relatif naik perlahan dan belum mengalami tanda kerusakan pada daun seledri dari hari ke-0 sampai hari ke-18. Kenaikan nilai susut bobot tertinggi dari hari ke-0 sampai hari ke-18 adalah $37,83 \%, 15,76 \%$ dan $11,63 \%$ terdapat pada perlakuan P0, P1 dan P5.

Kenaikan susut bobot yang tinggi menyebabkan terjadinya kerusakan pada daun seledri. Semakin meningkatnya susut bobot dikarenakan adanya uap air yang tinggi menyebabkan air yang berada dalam kemasan mengendap. Penurunan susut bobot selama penyimpanan dikarenakan oleh hilangnya air karena proses transpirasi. Transpirasi merupakan proses penguapan air dari dalam jaringan menuju keluar jaringan. Proses transpirasi menyebabkan kemunduran produk akibat berkurangnya air yang berdampak pada kehilangan susut bobot pada produk (Muchtadi, 1992).

Selama penyimpanan adanya proses transpirasi menyebabkan meningkatnya susut bobot karena penguapan air pada jaringan sayuran akibat perbedaan tekanan uap udara sekitarnya, sehingga semakin cepat proses transpirasi maka semakin cepat sayuran kehilangan bobotnya (Pudja, 2009). Seiring dengan lama penyimpanan, cadangan makanan dalam sayuran semakin menipis dan mengakibatkan susut bobot semakin meningkat (Hartono dkk, 2018). Penggunaan pengemasan plastik LDPE mampu menekan pengurangan bobot dan perubahan warna dibandingan sayuran tanpa pengemasan (Johansyah dkk, 2014).

\section{Color Difference}

Pengukuran perubahan warna pada daun seledri menggunakan alat Colorimeter. Perubahan warna yang diamati berdasarkan pengukuran menggunakan rumus Color difference $(\Delta \mathrm{E})$ pada daun seledri yang memperlihatkan perbedaan warna pada setiap perlakuan. Berdasarkan hasil analisis ragam, semua perlakuan tidak berpengaruh nyata pada hari ke-0 $(\mathrm{P}>0,05)$, pada hari ke-3, 6, 15 dan hari ke-18 berpengaruh sangat nyata $(\mathrm{P}<0,01)$, sedangkan hari ke-9 dan hari ke-12 berpengaruh nyata $(\mathrm{P}<0,05)$. Adapun hasil uji ragam dari nilai rata-rata uji (color 
difference) warna pada daun seledri selama penyimpanan disajikan pada Tabel 2.

Tabel 2. Nilai Rata-rata Color Difference Daun Seledri.

\begin{tabular}{cccccccc} 
Perlakuan & Hari 0 & Hari 3 & Hari 6 & Hari 9 & Hari 12 & Hari 15 & Hari 18 \\
P1 & $2.67 \mathrm{a}$ & $2.68 \mathrm{ab}$ & $4.36 \mathrm{c}$ & $12.15 \mathrm{a}$ & $14.77 \mathrm{~b}$ & $6.07 \mathrm{c}$ & $6.12 \mathrm{~d}$ \\
P2 & $2.83 \mathrm{a}$ & $6.45 \mathrm{~b}$ & $10.18 \mathrm{a}$ & $11.70 \mathrm{ab}$ & $20.07 \mathrm{a}$ & $15.05 \mathrm{ab}$ & $14.13 \mathrm{~b}$ \\
P3 & $2.79 \mathrm{a}$ & $7.41 \mathrm{a}$ & $9.10 \mathrm{ab}$ & $10.83 \mathrm{ab}$ & $20.02 \mathrm{a}$ & $19.19 \mathrm{a}$ & $18.97 \mathrm{a}$ \\
P4 & $2.87 \mathrm{a}$ & $2.96 \mathrm{c}$ & $7.37 \mathrm{~b}$ & $13.21 \mathrm{a}$ & $16.69 \mathrm{ab}$ & $12.23 \mathrm{~b}$ & $11.90 \mathrm{bc}$ \\
P5 & $2.33 \mathrm{a}$ & $2.39 \mathrm{~d}$ & $2.52 \mathrm{c}$ & $7.84 \mathrm{~b}$ & $14.36 \mathrm{~b}$ & $12.03 \mathrm{~b}$ & $9.52 \mathrm{~cd}$ \\
\hline
\end{tabular}

Keterangan: Huruf yang sama dibelakang nilai rata-rata pada kolom yang sama menunjukkan nilai yang tidak berbeda nyata $(\mathrm{P}>0,05)$.

Pada suhu penyimpanan $10 \pm 2^{\circ} \mathrm{C}$ semua perlakuan terjadi peningkatan nilai rata-rata dari hari ke-0 sampai pada hari ke-12 dan mengalami penurunan nilai rata-rata dari hari ke-15 sampai hari ke-18 karena setiap perlakuan mengalami penurunan nilai warna. Nilai warna terendah ditunjukkan oleh perlakuan P1 dengan nilai rata-rata 6,12 yang disertai adanya kerusakan tekstur daun menjadi layu, daun menguning dan adanya bercak hitam pada daun. Nilai warna tertinggi ditunjukkan oleh perlakuan P3 dengan nilai rata-rata 18,97 dengan daun berwarna hijau dan belum terjadi tanda adanya kerusakan pada daun seledri. Nilai $\Delta \mathrm{E}$ menggambarkan perbedaan warna total (color difference) perlakuan dengan kontrol.

Proses pelunakan pada sayuran berkaitan dengan proses transpirasi yang menyebabkan kandungan air dalam sayuran menjadi berkurang sehingga sayuran mengalami perubahan warna (menguning), batang mengkerut, kemudian terjadi pembusukan (Anggraini dan Permatasari, 2017). Perubahan warna tersebut menandakan daun seledri sudah mengalami kerusakan seiring dengan lama penyimpanan.

\section{Tekstur}

Berdasarkan hasil analisis ragam menunjukkan bahwa semua perlakuan tingkat ketebalan plastik LDPE tidak berpengaruh nyata terhadap tekstur daun seledri pada hari ke-0 $(\mathrm{P}>0,05)$, sedangkan berpengaruh sangat nyata pada hari ke-3, 6, 9, 12, 15, dan hari ke-18 $(\mathrm{P}<0,01)$. Pada penyimpanan hari ke0 , semua perlakuan tidak berbeda nyata. Pada hari ke3 sampai hari ke-18, semua perlakuan sangat berbeda nyata. Pengamatan hasil uji ragam terhadap tekstur daun seledri dapat dilihat pada Tabel 3.

Tabel 3. Nilai Rata-rata Tekstur Daun Seledri

\begin{tabular}{cccccccc}
\hline Perlakuan & Hari 0 & Hari 3 & Hari 6 & Hari 9 & Hari 12 & Hari 15 & Hari 18 \\
P0 & $0.0547 \mathrm{a}$ & $0.0421 \mathrm{f}$ & $0.0421 \mathrm{f}$ & $0.0372 \mathrm{f}$ & $0.0362 \mathrm{f}$ & $0.0352 \mathrm{f}$ & $0.0246 \mathrm{f}$ \\
P1 & $0.0547 \mathrm{a}$ & $0.0473 \mathrm{c}$ & $0.0465 \mathrm{c}$ & $0.0432 \mathrm{c}$ & $0.0412 \mathrm{~d}$ & $0.0385 \mathrm{~d}$ & $0.0382 \mathrm{~d}$ \\
P2 & $0.0547 \mathrm{a}$ & $0.0547 \mathrm{a}$ & $0.0526 \mathrm{a}$ & $0.0516 \mathrm{a}$ & $0.0491 \mathrm{a}$ & $0.0453 \mathrm{~b}$ & $0.0432 \mathrm{~b}$ \\
P3 & $0.0547 \mathrm{a}$ & $0.0497 \mathrm{~b}$ & $0.0486 \mathrm{~b}$ & $0.0479 \mathrm{~b}$ & $0.0474 \mathrm{~b}$ & $0.0467 \mathrm{a}$ & $0.0455 \mathrm{a}$ \\
P4 & $0.0547 \mathrm{a}$ & $0.0434 \mathrm{e}$ & $0.0429 \mathrm{~d}$ & $0.0426 \mathrm{~d}$ & $0.0428 \mathrm{c}$ & $0.0407 \mathrm{c}$ & $0.0393 \mathrm{c}$ \\
P5 & $0.0547 \mathrm{a}$ & $0.0437 \mathrm{~d}$ & $0.0426 \mathrm{e}$ & $0.0414 \mathrm{e}$ & $0.0385 \mathrm{e}$ & $0.0373 \mathrm{e}$ & $0.0325 \mathrm{e}$ \\
\hline
\end{tabular}

Keterangan: Huruf yang sama dibelakang nilai rata-rata pada kolom yang sama menunjukkan nilai yang tidak berbeda nyata $(\mathrm{P}>0,05)$.

Nilai tekstur terendah adalah $0,0246 \mathrm{~N}$ terdapat pada perlakuan P0 karena tingkat kekerasannya paling kecil dan sudah mengalami kerusakan seperti layu dan batang melembek. Nilai tekstur tertinggi adalah $0,0455 \mathrm{~N}$ dan $0,0432 \mathrm{~N}$ terdapat pada perlakuan $\mathrm{P} 3$ dan P2 karena tingkat kekerasan batang seledri relatif turun perlahan dan belum mengalami tanda kelayuan pada tekstur batang seledri dari hari ke-0 sampai hari ke-18. Proses kehilangan air dan pematangan yang terus berlanjut menyebabkan kandungan air dalam batang seledri akan semakin berkurang dan semakin lamanya waktu penyimpanan maka tekstur seledri menjadi semakin lunak. Hal ini sesuai dengan penelitian Zagory dan Kader (1988) bahwa konsentrasi oksigen $\left(\mathrm{O}_{2}\right)$ terlalu rendah dan konsentrasi karbondioksida $\left(\mathrm{CO}_{2}\right)$ terlalu tinggi mengakibatkan tekstur menurun tidak normal sehingga berdampak terjadinya pelunakan. Semakin lama penyimpanan menyebabkan tekstur semakin turun memicu pematangan sayuran sehingga tekstur sayuran semakin lunak (Fauziah dkk, 2016). 


\section{Kadar Air}

Berdasarkan hasil analisis ragam menunjukkan bahwa tingkat ketebalan plastik LDPE sebagai bahan kemasan daun seledri berpengaruh sangat nyata $(\mathrm{P}<0,01)$ tehadap kadar air daun seledri pada hari ke$6,9,12$, dan hari ke-15 serta berpengaruh nyata $(\mathrm{P}<0,05)$ terhadap kadar air daun seledri pada hari ke-
18. Sementara itu, pada hari ke- 0 dan hari ke- 3 semua perlakuan tidak berpengaruh nyata $(\mathrm{P}>0,05)$ terhadap kadar air daun seledri. Pengamatan hasil uji ragam terhadap kadar air daun seledri dapat dilihat pada Tabel 4.

Tabel 4. Nilai Rata-rata Kadar Air Daun Seledri.

\begin{tabular}{cccccccc} 
Perlakuan & Hari 0 & Hari 3 & Hari 6 & Hari 9 & Hari 12 & Hari 15 & Hari 18 \\
P0 & $90.17 \mathrm{a}$ & $89.20 \mathrm{a}$ & $77.06 \mathrm{c}$ & $75.56 \mathrm{c}$ & $71.92 \mathrm{~d}$ & $71.04 \mathrm{~d}$ & $70.21 \mathrm{c}$ \\
P1 & $90.10 \mathrm{a}$ & $89.99 \mathrm{a}$ & $89.22 \mathrm{a}$ & $88.94 \mathrm{a}$ & $88.17 \mathrm{~b}$ & $86.62 \mathrm{c}$ & $84.50 \mathrm{ab}$ \\
P2 & $90.69 \mathrm{a}$ & $90.55 \mathrm{a}$ & $90.47 \mathrm{a}$ & $90.44 \mathrm{a}$ & $90.44 \mathrm{a}$ & $90.27 \mathrm{a}$ & $89.95 \mathrm{a}$ \\
P3 & $90.67 \mathrm{a}$ & $90.59 \mathrm{a}$ & $90.48 \mathrm{a}$ & $90.44 \mathrm{a}$ & $90.40 \mathrm{a}$ & $90.30 \mathrm{a}$ & $90.22 \mathrm{a}$ \\
P4 & $90.45 \mathrm{a}$ & $89.75 \mathrm{a}$ & $89.45 \mathrm{a}$ & $89.28 \mathrm{a}$ & $89.26 \mathrm{ab}$ & $88.58 \mathrm{~b}$ & $81.95 \mathrm{ab}$ \\
P5 & $90.16 \mathrm{a}$ & $89.89 \mathrm{a}$ & $87.03 \mathrm{~b}$ & $86.45 \mathrm{~b}$ & $86.39 \mathrm{c}$ & $86.03 \mathrm{c}$ & $78.97 \mathrm{bc}$ \\
\hline
\end{tabular}

Keterangan: Huruf yang sama dibelakang nilai rata-rata pada kolom yang sama menunjukkan nilai yang tidak berbeda nyata $(\mathrm{P}>0,05)$.

Pada hari ke-0 sampai hari ke-3, tingkat kadar air daun seledri yang disimpan pada suhu $10 \pm 2{ }^{0} \mathrm{C}$ tidak berbeda nyata. Pada hari ke-6 dan hari ke-9 kadar air daun seledri pada perlakuan P0 dan P5 sangat berbeda nyata dari semua perlakuan. Pada hari ke-12, 15, dan hari ke-18, perlakuan P2 dan P3 tidak berbeda nyata. Nilai kadar air terendah adalah $70,21 \%$ terdapat pada perlakuan $\mathrm{P} 0$, dan nilai kadar air tertinggi adalah $90,22 \%$ dan $89,95 \%$ terdapat pada perlakuan P3 dan P2. Kandungan terbanyak yang dimiliki oleh daun seledri adalah air yang mencapai $93 \%$ dari total berat seledri (Wintagata dkk, 2019).

Tinggi rendahnya kadar air dalam bahan pangan menentukan kesegaran dan keawetan bahan pangan (Afrianto dan Liviawaty, 1989). Kadar air dalam bahan pangan berpengaruh besar dalam menentukan tekstur bahan pangan (Riansyah dkk, 2013). Kadar air yang rendah pada daun seledri cenderung menyebabkan mudahnya kelayuan pada tekstur daun seledri sehingga terjadi perubahan mutu daun seledri. Adanya proses transpirasi menyebabkan sayuran kehilangan air yang memengaruhi adanya perubahan tekstur, kelayuan dan menyebabkan kerusakan sayur (Sugianti dkk, 2014). Kehilangan air pada produk hortikultura yang disimpan selama periode penyimpanan tidak hanya menyebabkan hilangnya berat, tetapi juga menyebabkan kerusakan yang akhirnya terjadi penurunan kualitas (Fendriansah $\mathrm{dkk}, 2014)$.

\section{Evaluasi Sensori (Berdasarkan Uji Organoleptik)}

Evaluasi sifat sensori daun seledri dilakukan dengan penilaian uji organoleptik menggunakan uji skoring oleh 15 orang panelis. Uji skoring dilakukan terhadap warna, tingkat kesegaran, tekstur, dan aroma. Produk yang disajikan kehadapan panelis merupakan daun seledri yang sudah disimpan selama 18 hari penelitian.

\section{Warna}

Berdasarkan hasil uji ragam menunjukkan bahwa semua perlakuan berpengaruh sangat nyata $(\mathrm{P}<0,01)$. Nilai rata-rata uji skoring organoleptik terhadap warna pada pengamatan ke-18 terdapat pada Tabel 5.

Tabel 5. Nilai Rata- rata Uji Skoring Organoleptik Terhadap Warna Daun Seledri Pada Pengamatan ke18.

\begin{tabular}{cc}
\hline Perlakuan & Warna \\
P0 & $1.53 \mathrm{~d}$ \\
P1 & $2.00 \mathrm{c}$ \\
P2 & $3.00 \mathrm{~b}$ \\
P3 & $4.73 \mathrm{a}$ \\
P4 & $3.13 \mathrm{~b}$ \\
P5 & $2.27 \mathrm{c}$ \\
\hline
\end{tabular}

Nilai tertinggi uji skoring organoleptik terhadap warna daun seledri diperoleh pada perlakuan P3 dengan tingkat ketebalan plastik LDPE $(0,04 \mathrm{~mm})$ selama penyimpanan 18 hari yaitu sebesar 4,73 (kriteria hijau segar). Sedangkan nilai terendah uji skoring organoleptik terhadap warna daun seledri diperoleh pada P0 (kontrol) tanpa perlakuan yaitu sebesar 1,53 (kriteria kuning sekali). Warna merupakan bagian dari sensori yang dapat dilihat langsung oleh panelis untuk mengetahui mutu daun seledri. Suatu bahan pangan dinilai bergizi jika memiliki warna yang masih segar dan sesuai saat dipandang (Budiyanto, 2012). Tanda-tanda pertama dari adanya penurunan kualitas dan penurunan umur simpan yang menjadi ciri kerusakan daun seledri yaitu hilangnya warna hijau dan timbul browning pada ujung tangkai daun (Rizzo dan Muratore, 2009). 


\section{Tingkat Kesegaran}

Berdasarkan hasil uji ragam menunjukkan bahwa semua perlakuan berpengaruh sangat nyata $(\mathrm{P}<0,01)$. Nilai rata-rata uji skoring organoleptik terhadap tingkat kesegaran pada pengamatan ke-18 terdapat pada Tabel 6.

Tabel 6. Nilai Rata- rata Uji Skoring Organoleptik Terhadap Tingkat Kesegaran Daun Seledri Pada Pengamatan ke-18.

\section{Perlakuan}

P0

$\mathrm{P} 1$

$\mathrm{P} 2$

$\mathrm{P} 3$

$\mathrm{P} 4$

P5

\section{Tingkat Kesegaran}

$1.87 \mathrm{~d}$

$2.13 \mathrm{~d}$

$3.80 \mathrm{~b}$

$4.87 \mathrm{a}$

$2.67 \mathrm{c}$

$2.60 \mathrm{c}$
Nilai tertinggi uji skoring organoleptik terhadap tingkat kesegaran daun seledri diperoleh pada perlakuan $\mathrm{P} 3$ dengan tingkat ketebalan plastik LDPE $(0,04 \mathrm{~mm})$ selama penyimpanan 18 hari yaitu sebesar 4,87 (kriteria kenampakan masih segar). Nilai terendah uji skoring organoleptik terhadap tingkat kesegaran daun seledri diperoleh pada P0 tanpa perlakuan yaitu sebesar 1,87 (kriteria tidak bisa digunakan atau rusak). Kesegaran produk hortikultura cenderung cepat menurun disebabkan oleh proses transpirasi yang berlangsung sangat cepat sehingga mudah mengalami kelayuan (Warisno dan Dahana, 2007). Tingkat kesegaran produk hortikultura semakin berkurang ketika susut bobot semakin tinggi (Rohaeti dkk, 2010).

\section{Tekstur}

Berdasarkan hasil ragam menunjukkan bahwa semua perlakuan berpengaruh sangat nyata $(\mathrm{P}<0,01)$. Nilai rata-rata uji skoring organoleptik terhadap tekstur pada pengamatan ke-18 terdapat pada Tabel 7 .

Tabel 7. Nilai Rata- rata Uji Skoring Organoleptik Terhadap Tekstur Daun Seledri Pada Pengamatan ke18.

\begin{tabular}{cc|}
\hline Perlakuan & Tekstur \\
P0 & $1.13 \mathrm{e}$ \\
P1 & $2.47 \mathrm{c}$ \\
P2 & $3.27 \mathrm{~b}$ \\
P3 & $4.67 \mathrm{a}$ \\
P4 & $3.33 \mathrm{~b}$ \\
P5 & $1.73 \mathrm{~d}$ \\
\hline
\end{tabular}

Nilai tertinggi uji skoring organoleptik terhadap tekstur daun seledri diperoleh pada perlakuan P3 dengan tingkat ketebalan plastik LDPE $(0,04 \mathrm{~mm})$ selama penyimpanan 18 hari yaitu sebesar 4,67 (tegar dan segar). Nilai terendah uji skoring organoleptik terhadap tekstur daun seledri diperoleh pada P0 (kontrol) tanpa perlakuan yaitu sebesar 1,13 (kriteria sangat layu dan tidak bisa digunakan). Perubahan tekstur dari keras menjadi lunak yang terjadi pada sayuran terjadi karena adanya proses kelayuan akibat transpirasi (Sugianti dkk, 2014). Transpirasi yang terjadi menyebabkan berkurangnya kadar air yang memengaruhi perubahan tekstur sayuran menjadi tidak segar lagi (Nur'aini dan Apriyani, 2015).

\section{Aroma}

Berdasarkan hasil uji ragam menunjukkan bahwa semua perlakuan berpengaruh sangat nyata $(\mathrm{P}<0,01)$. Nilai rata-rata uji skoring organoleptik terhadap aroma pada pengamatan ke-18 terdapat pada Tabel 8 .

Tabel 8. Nilai Rata- rata Uji Skoring Organoleptik Terhadap Aroma Daun Seledri Pada Pengamatan ke18.

\begin{tabular}{cc} 
Perlakuan & Aroma \\
\hline P0 & $1.27 \mathrm{~d}$ \\
P1 & $1.73 \mathrm{c}$ \\
P2 & $3.07 \mathrm{~b}$ \\
P3 & $5.00 \mathrm{a}$ \\
P4 & $2.73 \mathrm{~b}$ \\
P5 & $1.87 \mathrm{c}$ \\
\hline
\end{tabular}

Nilai tertinggi uji skoring organoleptik terhadap aroma daun seledri diperoleh pada perlakuan P3 dengan tingkat ketebalan plastik LDPE $(0,04 \mathrm{~mm})$ selama penyimpanan 18 hari yaitu sebesar 5.00 (sangat beraroma). Nilai terendah uji skoring organoleptik terhadap aroma daun seledri diperoleh pada P0 (kontrol) tanpa perlakuan yaitu sebesar 1.27 (tidak berbau seledri atau bau busuk). Aroma merupakan bau yang ditimbulkan oleh suatu produk pangan untuk mengetahui kesegaran bau mutu produk pangan (Budiyanto, 2012). Penyimpanan pada suhu rendah dilakukan untuk komoditas sayuran yang mudah rusak karena adanya perubahanperubahan bau, tekstur dan warna, mengurangi kehilangan air dan pelayuan, mengurangi kerusakan karena aktivitas mikroba agar dapat mempertahankan aroma (Samad, 2006).

\section{Umur Simpan}

Berdasarkan hasil pengamatan umur simpan daun seledri menunjukkan bahwa tingkat ketebalan plastik polietilen densitas rendah dengan penyimpanan suhu dingin memengaruhi umur simpan daun seledri. Adapun tabel dari hasil pengamatan umur simpan daun seledri dapat dilihat pada Tabel 9.

Umur simpan daun seledri yang tanpa diberikan perlakuan P0 (kontrol) bertahan selama 5 hari dengan adanya ciri-ciri kerusakan daun seledri pada hari ke- 
6 timbulnya bercak kecoklatan, daun mengalami kelayuan dan daun menguning. Umur simpan daun seledri yang dikemas plastik LDPE dengan ketebalan $0,02 \mathrm{~mm}$ bertahan selama 9 hari dengan adanya ciriciri kerusakan daun seledri pada hari ke-10 timbulnya daun menguning, ada sebagian daun yang layu dan adanya bercak kecoklatan pada daun. Umur simpan daun seledri yang dikemas plastik LDPE dengan ketebalan $0,03 \mathrm{~mm}$ bertahan selama 15 hari dengan adanya ciri-ciri kerusakan daun seledri pada hari ke16 timbulnya daun seledri menguning.

Tabel 9. Nilai Rata- rata Uji Skoring Organoleptik Terhadap Umur Simpan Daun Seledri Pada Pengamatan ke-18.

\begin{tabular}{lc}
\hline Perlakuan & Umur Simpan \\
P0 (kontrol) & 5 hari \\
P1 $(0,02 \mathrm{~mm})$ & 9 hari \\
P2 $(0,03 \mathrm{~mm})$ & 15 hari \\
P3 $(0,04 \mathrm{~mm})$ & 18 hari \\
P4 $(0,05 \mathrm{~mm})$ & 12 hari \\
P5 $(0,06 \mathrm{~mm})$ & 9 hari \\
\hline
\end{tabular}

Umur simpan daun seledri yang dikemas plastik LDPE dengan ketebalan 0,04 $\mathrm{mm}$ bertahan selama 18 hari. Selama 18 hari penyimpanan daun seledri masih segar dan belum mengalami kerusakan. Umur simpan daun seledri yang dikemas plastik LDPE dengan ketebalan $0,05 \mathrm{~mm}$ bertahan selama 12 hari dengan adanya ciri-ciri kerusakan daun seledri pada hari ke13 timbulnya bercak kecoklatan pada daun dan daun menguning. Umur simpan daun seledri yang dikemas plastik LDPE dengan ketebalan 0,06 $\mathrm{mm}$ bertahan selama 9 hari dengan adanya ciri-ciri kerusakan daun seledri pada hari ke-10 timbulnya bercak kecoklatan pada daun dan daun menguning. Umur simpan produk segar hortikultural seperti sayuran tidak mencantumkan tanggal kadaluarsa, namun dapat ditentukan dari kenampakan produk (Mahendra dkk, 2016).

\section{KESIMPULAN DAN SARAN}

\section{Kesimpulan}

Berdasarkan hasil penelitian, disimpulkan bahwa ketebalan plastik polietilen densitas rendah sebagai bahan pengemas daun seledri berpengaruh sangat nyata terhadap susut bobot, warna, tekstur, kadar air, tingkat kesegaran, dan aroma daun seledri. Perlakuan terbaik diperoleh dari ketebalan plastik LDPE ukuran 0,04 dengan susut bobot 4,64 \%, warna 18,87, tekstur $0,0455 \mathrm{~N}$, kadar air 90,22\%, tingkat kesegaran 4,87 dan aroma 5,00. Ketebalan plastik polietilen densitas rendah ukuran $0,04 \mathrm{~mm}$ terbukti dapat mempertahankan mutu daun seledri dengan umur simpan 18 hari penyimpanan.

\section{Saran}

Berdasarkan hasil penelitian yang menunjukkan ketebalan plastik polietilen densitas rendah ukuran 0,04 $\mathrm{mm}$ dapat memperpanjang umur simpan daun seledri paling lama maka perlu dilakukan penelitian lanjutan terkait pengemasan yang lebih baik dari plastik polietilen densitas rendah ukuran $0,04 \mathrm{~mm}$ untuk mempertahankan mutu dan memperpanjang umur simpan daun seledri.

\section{DAFTAR PUSTAKA}

Afrianto, I. E., dan Liviawaty, I. E. (1989). Pengawetan dan pengolahan ikan. Kanisius.

Anggraini, R., dan Permatasari, N. D. (2018). Pengaruh lubang perforasi dan jenis plastik kemasan terhadap kualitas sawi hijau (brassica juncea 1.). Jurnal Penelitian Pascapanen Pertanian, 14(3), 154-162.

Arisandi, R., dan Sukohar, A. (2016). Seledri (apium graveolens 1) sebagai agen kemopreventif bagi kanker. Jurnal Majority, 5(2), 95-100.

Budiyanto, M. P. (2015). Pengaruh jenis kemasan dan kondisi penyimpanan terhadap mutu dan umur simpan produk keju lunak rendah lemak. Skripsi. Institut Pertanian Bogor.

Elidar, Y. (2018). Budidaya tanaman seledri di dalam pot dan manfaatnya untuk kesehatan. Jurnal Abdimas Mahakam, 2(1), 42-47.

Fauziah, D., dan Asgar, A. (2016). Pengaruh suhu penyimpanan dan jenis kemasan serta lama penyimpanan terhadap karaktristik tomat (solanum lycopersicum l) organik (Doctoral Dissertation, Fakultas Teknik Unpas).

Fendriansah, Tamrin, dan Oktafri. (2014). Pengaruh media penyimpanan (biji plastik) terhadap umur simpan wortel segar (daucus carrota 1.) Jurnal Teknik Pertanian Lampung, 3 (2), 111-118.

Hartono, N. A. D., Sutrisno, S., dan Darmawati, E. (2018). Pengemasan untuk mengurangi resiko cemaran timbal $(\mathrm{pb})$ dan penurunan mutu pada sistem penjualan buah pedagang kaki lima. Jurnal Penelitian Pascapanen Pertanian, 15(1).

Indrasari, M.A. 2009. Pengemasan atmosfer termodifikasi seledri (apium graveolens L.). Skripsi. Institut Pertanian Bogor. Bogor.

Johansyah, A., dan Kusdiantini, E. (2014). Pengaruh plastik pengemas low density polyethylene (LDPE), high density polyethylene (HDPE) dan polipropilen (PP) terhadap penundaan 
kematangan buah tomat (Lycopersicon esculentum. Mill). Anatomi Fisiologi, 22(1), 46-57.

Mahendra, I. P. A. O., dan Pudja, I. R. P. (2015). Pengaruh package icing terinterupsi terhadap mutu brokoli (brassica oleracea, 1.) selama penyimpanan. Jurnal BETA (Biosistem dan Teknik Pertanian), 4(1).

Muchtadi, T.R. 1992. Fisiologi Pascapanen Sayuran dan Buah-buahan. Departemen Pendidikan dan Kebudayaan. Jendral Pendidikan Tinggi. PAU. IPB. Bogor.

Nur'aini, H., dan Apriyani, S. (2015). Penggunaan kitosan untuk memperpanjang umur simpan buah duku (lansium domesticum Corr). AGRITEPA, 1(2), 195-210.

Pudja, I. A. R. P. 2009. Laju respirasi dan susut bobot buah salak bali segar pada pengemasan plastik polyethylene selama penyimpanan dalam atmosfer termodifikasi. Agrotekno 15 (1), 8-11.

Riansyah, A., Supriadi, A., dan Nopianti, R. (2013). Pengaruh perbedaan suhu dan waktu pengeringan terhadap karakteristik ikan asin sepat siam (trichogaster pectoralis) dengan menggunakan oven. Jurnal Fishtech, 2(1), 53-68..

Rizzo, V., dan Muratore, G. (2009). Effects of packaging on shelf life of fresh celery. Journal of Food Engineering, 90(1), 124-128.

Rohaeti, E., Syarief, R., dan Hasbullah, R. (2010). Perlakuan Uap Panas (Vapor Heat Treatment) untuk Disinfestasi Lalat Buah dan Mempertahankan Mutu Buah Belimbing (Averrhoa carambola L.). Jurnal Keteknikan Pertanian, 24(1).

Samad, M. Y. (2012). Pengaruh penanganan pasca panen terhadap mutu komoditas hortikultura. Jurnal Sains dan Teknologi Indonesia, 8(1).

Saragih, H. O., Dharma, I. P., dan Astawa, I. N. G. Pengaruh ketebalan plastik polyethylene densitas rendah terhadap umur simpan bawang daun (allium fistulosum 1.). E-Jurnal Agroekoteknologi Tropika (Journal of Tropical Agroecotechnology), 363-373.

Sugianti, C., Hasbullah, R., Purwanto, Y. A., dan Setyabudi, D. A. (2012). Kajian pengaruh iradiasi dosis 0.75 kgy terhadap kerusakan dingin (chilling injury) pada buah mangga gedong selama penyimpanan. Jurnal Teknik Pertanian LampungVol, 3(2), 195-204.

Syahidah, F. M., dan Sulistiyaningsih, R. (2018). Potensi seledri (apium graveolens) untuk pengobatan. Farmaka, 16(1), 55-62.
Warisno dan Dahana, K. 2007. Budidaya Rambutan. CV Aneka Ilmu, Semarang.

Wintagata, K. A., Hartiati, A., dan Admadi, B. Aplikasi commodity system assessment method (csam) pada distribusi seledri (apium graveolens 1.) dari petani di kecamatan baturiti ke pengecer. Jurnal Rekayasa dan Manajemen Agroindustri, 7(2), 200-211.

Zagory, D., dan Kader, A. A. (1988). Modified atmosphere packaging of fresh produce. Food Technol, 42(9), 70-77. 